\title{
LINKING POLLINATOR OCCURRENCE IN FIELD MARGINS TO POLLINATOR VISITATION TO A MASS-FLOWERING CROP
}

\author{
Marjaana Toivonen ${ }^{* 1,2}$, Irina Herzon ${ }^{2,3}$, Jenni Toikkanen ${ }^{1,2}$, Mikko Kuussaari' \\ ${ }^{1}$ Finnish Environment Institute (SYKE), Biodiversity Centre, Latokartanonkaari 11, Fl-0079o Helsinki, Finland \\ ${ }^{2}$ University of Helsinki, Department of Agricultural Sciences, P.O. Box 27, Fl-00014 University of Helsinki, Finland \\ ${ }^{3} \mathrm{Helsinki}$ Institute of Sustainability Science, HELSUS, P.O. Box 65, Fl-00014 University of Helsinki, Finland
} Journal of Pollination Ecology,
28(12), 2021, pp 153-166

DOI: $10.26786 / 1920-$

$7603(2021) 623$

Received 22 June 2020, accepted 1 July 2021

*Corresponding author: marjaana.toivonen@syke.fi

\begin{abstract}
Uncultivated field margins are important refugia for pollinating insects in agricultural landscapes. However, the spill-over of pollination services from field margins to adjacent crops is poorly understood. This study (i) examined the effects of landscape heterogeneity on pollinator occurrence in permanent field margins and pollinator visitation to adjacent mass-flowering turnip rape (Brassica rapa ssp. oleifera) in boreal agricultural landscapes, and (ii) tested whether pollinator abundance and species richness in field margins predict abundance and species richness of crop visitors. Pollinators visiting the crop were more affected by landscape heterogeneity than pollinators in adjacent margins. Species richness, total abundance, and the abundance of syrphid flies visiting the crop increased with increasing landscape heterogeneity, whereas, in field margins, landscape heterogeneity had little effect on pollinators. In field-dominated homogeneous landscapes, wild pollinators rarely visited the crop even if they occurred in adjacent margins, whereas in heterogeneous landscapes, differences between the two habitats were smaller. Total pollinator abundance and species richness in field margins were poor predictors of pollinator visitation to adjacent crop. However, high abundances of honeybees and bumblebees in margins were related to high numbers of crop visitors from these taxa. Our results suggest that, while uncultivated field margins help pollinators persist in boreal agricultural landscapes, they do not always result in enhanced pollinator visitation to the adjacent crop. More studies quantifying pollination service delivery from semi-natural habitats to crops in different landscape settings will help develop management approaches to support crop pollination.
\end{abstract}

Keywords-Bee, butterfly, field edge, landscape heterogeneity, turnip rape, hoverfly

\section{INTRODUCTION}

Agricultural intensification has led to pollinator decline that poses a serious threat to food production, ecosystem stability and human well-being (Potts et al. 2016). Intensive agricultural practices and the loss of semi-natural habitats have reduced the supply of floral and nesting resources to pollinators (Scheper et al. 2014; Baude et al. 2016; Potts et al. 2016). To mitigate the negative trends, researchers have suggested diversifying farming systems (Kremen \& Miles 2012) and adopting ecological intensification (Kovács-Hostyánszki et al. 2017). Both strategies include retaining, creating and managing semi-natural habitats such as flower strips (Haaland et al. 2011), hedgerows (M'Gonigle et al. 2015) and fallows (Toivonen et al. 2015) around crop fields.

While the importance of semi-natural habitats for pollinators is well-established (Öckinger \& Smith 2007; Ricketts et al. 2008; Garibaldi et al. 2011), the extent to which pollinators and pollination services spill over into adjacent crops is relatively poorly understood. Several studies have assessed how crop pollination services decline with distance from semi-natural habitats (Ricketts et al. 2008; Carvalheiro et al. 2010; Bailey et al. 2014; Woodcock et al. 2016). However, fewer studies have measured both pollinator occurrence in semi- 
natural habitats and crop pollination service, i.e. crop visitation, stigmatic pollen loads and/or seed set, in adjacent fields (but see Stanley \& Stout 2014; Sardiñas \& Kremen 2015; Ganser et al. 2018; Knapp et al. 2019).

High pollinator abundance and diversity in a semi-natural habitat may not result in good pollination in an adjacent crop, if the crop attracts different pollinators than wild plants growing in the semi-natural habitat (Sardiñas \& Kremen 2015). Alternatively, if pollinators are limited, coflowering plants that have overlapping pollinator communities may compete for shared pollinators (Grab et al. 2017). In addition, crop-visiting pollinators differ in their pollination efficiency due to differences in behavior and morphology (Garibaldi et al. 2013; Phillips et al. 2018). Thus, the benefits of semi-natural habitats to crop pollination in adjacent fields may vary depending on crops, characteristics of semi-natural habitats, and pollinator abundance and species composition in the landscape.

Surrounding landscape also modifies the effects of semi-natural habitats on pollinators (Concepción et al. 2012; Kennedy et al. 2013; Scheper et al. 2013). The best efficiency of conservation measures for pollinators is generally expected in simple landscapes with intermediate cover of semi-natural habitats (Concepción et al. 2012; Scheper et al. 2013), but the types and quality of semi-natural habitats (e.g. forest vs. seminatural grasslands) and arable land (e.g. organic vs. conventional fields) also matter (Öckinger et al. 2012; Kennedy et al. 2013; Bergman, DánielFerreira et al. 2018). However, it is poorly understood whether landscape structure similarly affects pollinator occurrence in semi-natural habitats and pollination service delivery to adjacent crops (but see Fijen et al. 2019).

In Northern Europe, uncultivated field margins are the most widespread open semi-natural habitat in agricultural landscapes dominated by arable land and forests. Besides many other environmental benefits (Haddaway et al. 2018), field margins provide food, and nesting and overwintering resources for pollinators (Lagerlöf et al. 1992; Bäckman \& Tiainen 2002). The use of field margins by pollinators is influenced by landscape context, with the cover of forest found to be important in several studies (Öckinger et al.
2012; Toivonen et al. 2017; Bergman et al. 2018). As compared to an arable matrix, forest may enhance resource provision and dispersal for some pollinator taxa, while depriving resources or acting as barrier for others (Öckinger et al. 2012).

This study compared pollinator occurrence in permanent uncultivated field margins and pollinator visitation to mass-flowering turnip rape (Brassica rapa ssp. oleifera) in adjacent fields across a landscape heterogeneity gradient in boreal farmland. We aimed to answer two questions: (i) Does landscape heterogeneity differently affect pollinator occurrence in field margins and pollinator visitation to the adjacent crop? (ii) Is pollinator abundance or species richness in field margins a reliable predictor of abundance and species richness of crop visitors in adjacent fields?

\section{MATERIALS AND METHODS}

\section{STUDY SITES}

The study was conducted in 34 spring-sown turnip rape fields and their permanent margins in boreal farmland landscapes of Southern Finland $\left(60^{\circ} 9^{\prime}-60^{\circ} 46^{\prime} \mathrm{N}, 23^{\circ} 49^{\prime}-26^{\circ} 2^{\prime} \mathrm{E}\right)$ (Fig. 1). In the study region, land use is dominated by forests and arable land (68 and 23\% of land area, respectively). Each study site consisted of one field margin and the area in its proximity in the turnip rape field, where pollinators were monitored. The study sites were chosen by first selecting turnip rape fields in landscapes ranging from field-dominated homogenous landscapes to heterogeneous ones with high forest cover, and then systematically choosing one margin for each field. In fielddominated landscapes, the field margin that situated farthest from forest was selected, whereas in heterogeneous landscapes, the margin closest to

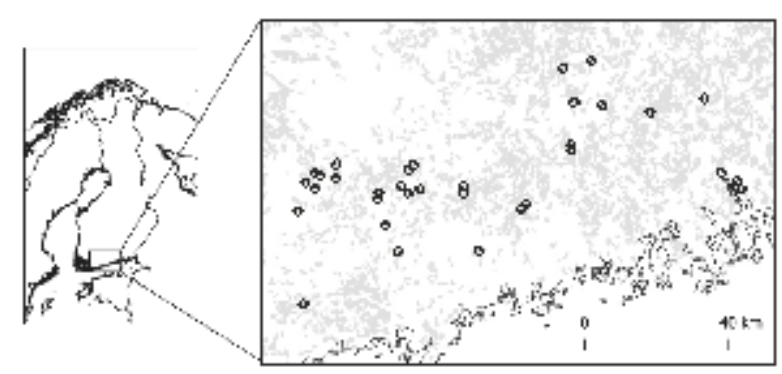

Figure 1. Locations of the 34 study fields (characterised in Tab. 1) in Southern Finland. Arable land is shown in the map in grey colour. 
forest without being bordered by forest was chosen. The systematic selection helped to ensure a wide range of landscape heterogeneity among the study sites (Tab. 1), while selection bias was avoided. The minimum distance between the study sites was $1 \mathrm{~km}$. Although bees can forage over larger distances, they prefer nearby resources when available (Couvillon et al. 2015; Geib et al. 2015; Redhead et al. 2016).

Landscape heterogeneity was described using three measures: distance to forest, and the percentage cover of forest within the buffers of $500-\mathrm{m}$ and $1-\mathrm{km}$ radii around the central point of each site. The measures of landscape heterogeneity were strongly correlated with each other (Pearson's $r$ for distance to forest and forest cover in the 500-m buffer - 0.75 ; for distance to forest and forest cover in the 1-km buffer -0.67 ; and for forest cover in the $500-\mathrm{m}$ and $1-\mathrm{km}$ buffers 0.91 ; all $P<$ $0.001)$. The cover of forest and other land use types
(Tab. 1) was calculated using ArcGIS 10.5.1 (Esri 2017) with data derived from the CORINE Land Cover 2012 database (Finnish Environment Institute 2014). In addition, crop types within the 500-m buffers were recorded during fieldwork (Tab. 1). Honeybee hives were present in 12 out of 34 buffers of the $500-\mathrm{m}$ radius.

\section{POLLINATOR MONITORING}

In the field margins, pollinators were counted applying the standard line-transect method (Pollard \& Yates 1993). The transect counts were conducted five times at approximately ten-day intervals, from $6^{\text {th }}$ of June until $23^{\text {rd }}$ of August 2017. A permanent $50 \mathrm{~m}$-long route along the margin was walked at a steady speed (without stops about $1 \mathrm{~min} 40 \mathrm{sec}$ per $50 \mathrm{~m}$ ) and all the individuals within an imaginary box of $5 \mathrm{~m} \times 5 \mathrm{~m} \times 5 \mathrm{~m}$ ahead of the counter were recorded. Each counting time, the transect was walked twice. Bumblebees and

Table 1.Landscape characteristics of the study sites. Percentage cover of land use types were calculated within 500-m and 1-km buffers. Crop types were recorded only within the 500-m buffers during fieldwork. Distance to forest was measured from the sampling location closest to forest.

\begin{tabular}{lllll}
\hline & Mean & SD & Min & Max \\
\hline Land use in 500-m buffer & & & & \\
Arable land (\%) & 54 & 24 & 9 & 96 \\
$\quad$ Turnip rape and oilseed rape (\%) & 14 & 11 & 2 & 52 \\
Other insect-pollinated crops (\%) & 1 & 2 & 0 & 9 \\
$\quad$ Cereals (\%) & 31 & 19 & 0 & 68 \\
$\quad$ Perennial grasslands (\%) $)^{2}$ & 8 & 11 & 0 & 44 \\
Forest (\%) & 30 & 26 & 0 & 80 \\
Built-up area (\%) & 3 & 13 & 0 & 69 \\
Wetland (\%) & 1 & 3 & 0 & 20 \\
Water (\%) & 0 & 2 & 0 & 14 \\
Land use in 1-km buffer & & & & \\
Arable land (\%) & & 18 & 6 & 75 \\
Forest (\%) & 41 & 24 & 6 & 100 \\
Built-up area (\%) & 44 & 8 & 0 & 44 \\
Wetland (\%) & 3 & 4 & 0 & 24 \\
Water (\%) & 1 & 5 & 0 & 28 \\
Distance to forest (m) & 2 & 7 & 7 & 421 \\
Flower coverage (\%) in field margins ${ }^{3}$ & 21 & 7 & 41 \\
\hline
\end{tabular}

${ }^{1}$ Field margins are included in arable land.

${ }^{2}$ Perennial grasslands included sown cultivated grasslands and perennial fallows.

3 Coverage of insect-pollinated plants in flower, averaged over five visits in each margin. 
butterflies were recorded in the first walk, after which the counter stopped to make notes of field margin vegetation for 3-5 minutes, and then walked back recording honeybees, solitary bees and syrphid flies. Bumblebees and butterflies were identified to species. Only exceptions were Bombus lucorum -group (B. lucorum, B. terrestris, B. cryptarum and B. magnus) and cuckoo bumblebees (subgenus: Psithyrus), except for B. rupestris. For solitary bees and syrphid flies, only total numbers were recorded. Vegetation observations in the field margins included total coverage (\%) of insectpollinated plants in flower, and flower abundances of the most important groups of insect-pollinated plants, which were estimated using four abundance classes.

In the turnip rape fields, pollinators visiting crop flowers were monitored in observational squares. Although being a relatively poor method for estimating species richness, observational squares have been shown to detect similar species composition to those based on transect counts (Westphal et al. 2008). In each turnip rape field, pollinators visiting crop flowers were monitored in four $2 \times 2 \mathrm{~m}$ squares. The squares were placed at 5 and $20 \mathrm{~m}$ distances from the studied field margin so that, at both distances, two squares were in parallel, $50 \mathrm{~m}$ from each other. The squares were marked with bamboo sticks and monitored for 5 minutes three times during crop flowering, between $28^{\text {th }}$ of June and $28^{\text {th }}$ of July 2017. All pollinator individuals visiting turnip rape flowers and touching the reproductive parts of the flower were recorded. Bees and butterflies were identified at the same level as in the field margins, but syrphid flies were identified to subfamilies Syrphinae and Eristalinae. Other crop visitors were identified at varied taxonomic levels (Appendix I, Tab. A.1).

The data collection methods were different in field margins and turnip rape fields, because, in field margins, we aimed to assess the margins' value for pollinators, whereas in turnip rape fields, measuring potential crop pollination service was our interest. Since field margins often have heterogeneous vegetation, it is important to observe pollinators over a large area of the margins and at several times of the summer, also when the adjacent crop is not flowering. However, observational squares are more practical in monitoring pollinator visitation to crop flowers, and they also allow linking pollinator visits to crop yield. The effects of pollinator visits on turnip rape yield in the same study system were reported by Toivonen et al. (2019): The number of seeds per silique increased with increasing number of flower visits, indicating enhanced crop pollination, whereas species richness of pollinators had no yield effect.

Pollinator monitoring in the field margins and in the crop was conducted between 9 a.m. and 6 p.m., in weather conditions allowing insect activity. Minimum temperature was $15{ }^{\circ} \mathrm{C}$ in sunny or partly cloudy non-windy weather, $16{ }^{\circ} \mathrm{C}$ in cloudy non-windy weather, and $17^{\circ} \mathrm{C}$ in cloudy weather with moderate wind.

\section{StATISTICAL ANALYSES}

Prior to the statistical analyses, pollinator data were aggregated by fields and margins to get the total number of individuals and species observed on each field and margin.

The effects of landscape heterogeneity on pollinator species richness and abundance in adjacent fields and margins were tested using generalised linear mixed models. Although the differences in species richness and abundance between the two habitat types may partly result from different monitoring methods, the methodological difference should not affect the interaction between habitat type and landscape heterogeneity, on which this analysis focused. Because the three measures of landscape heterogeneity were strongly correlated, their effects were tested in separate models. Poisson errors were assumed in the models unless the data were overdispersed, in which case negative binomial models were selected. Response variables in the models were species richness, total abundance, and abundances of honeybees, bumblebees, solitary bees, syrphid flies and butterflies. In crop fields, species richness and total abundance included also other minor pollinator groups that were not counted in field margins. Explanatory variables were habitat type (crop field and field margin), landscape heterogeneity (distance to forest, forest cover within the 500-m buffer, or forest cover within the 1-km buffer) and interaction between the two variables. Coverage of insect-pollinated plants in flower in field margins 
Table 2. Generalised linear mixed model results of the interactive effects of habitat type (field vs. margin) and landscape heterogeneity (distance to forest, forest cover within the 500-m buffer, or forest cover within the 1-km buffer) on species richness, total pollinator abundance, and abundances of five pollinator groups.

\begin{tabular}{|c|c|c|c|c|c|c|c|c|c|c|c|c|c|}
\hline & \multicolumn{4}{|c|}{ Distance to forest (km) } & \multicolumn{4}{|c|}{ Forest (\%) in 500-m buffer } & \multicolumn{4}{|c|}{ Forest (\%) in 1-km buffer } & \multirow[b]{2}{*}{ Model type } \\
\hline & Estimate & SE & Z & $\mathrm{P}$ & Estimate & SE & z & $P$ & Estimate & SE & z & $P$ & \\
\hline \multicolumn{14}{|l|}{ Species richness } \\
\hline (Intercept) & 1.629 & 0.180 & 9.047 & $<0.001$ & 1.210 & 0.188 & 6.443 & $<0.001$ & 1.028 & 0.223 & 4.617 & $<0.001$ & \multirow[t]{4}{*}{ poisson } \\
\hline Margin & 0.233 & 0.137 & 1.699 & ns & 0.547 & 0.157 & 3.497 & $<0.001$ & 0.721 & 0.215 & 3.348 & $<0.001$ & \\
\hline Landscape heterogeneity & -2.389 & 0.818 & -2.920 & $<0.01$ & 0.004 & 0.003 & 1.436 & ns & 0.007 & 0.003 & 2.142 & $<0.05$ & \\
\hline Flower coverage in margin & 0.009 & 0.007 & 1.338 & ns & 0.011 & 0.007 & 1.742 & ns & 0.012 & 0.007 & 1.764 & ns & \\
\hline \multicolumn{14}{|l|}{ Total abundance } \\
\hline (Intercept) & 3.104 & 0.264 & 11.741 & $<0.001$ & 2.347 & 0.292 & 8.038 & $<0.001$ & 2.074 & 0.338 & 6.134 & $<0.001$ & \multirow[t]{5}{*}{ neg. bin. } \\
\hline Margin & 0.180 & 0.188 & 0.961 & ns & 0.739 & 0.228 & 3.246 & $<0.01$ & 0.990 & 0.309 & 3.199 & $<0.01$ & \\
\hline Landscape heterogeneity & -3.207 & 1.138 & -2.818 & $<0.01$ & 0.010 & 0.004 & 2.623 & $<0.01$ & 0.013 & 0.004 & 3.025 & $<0.01$ & \\
\hline Flower coverage in margin & 0.010 & 0.010 & 1.038 & ns & 0.014 & 0.010 & 1.476 & ns & 0.014 & 0.010 & 1.449 & ns & \\
\hline Margin * Landscape heterogeneity & 2.241 & 1.405 & 1.595 & ns & -0.010 & 0.005 & -1.950 & ns & -0.013 & 0.006 & -2.213 & $<0.05$ & \\
\hline Margin & -1.127 & 0.358 & -3.148 & $<0.01$ & -0.458 & 0.336 & -1.363 & ns & -0.142 & 0.450 & -0.316 & ns & \multirow{4}{*}{ neg. bin. } \\
\hline Landscape heterogeneity & -0.473 & 1.589 & -0.298 & ns & 0.003 & 0.006 & 0.439 & ns & 0.004 & 0.007 & 0.540 & ns & \\
\hline Flower coverage in margin & -0.007 & 0.021 & -0.350 & ns & -0.007 & 0.021 & -0.319 & ns & -0.007 & 0.021 & -0.349 & ns & \\
\hline Margin * Landscape heterogeneity & 2.115 & 1.997 & 1.059 & ns & -0.016 & 0.009 & -1.724 & ns & -0.018 & 0.010 & -1.908 & ns & \\
\hline \multicolumn{14}{|l|}{ Bumblebees } \\
\hline (Intercept) & 0.309 & 0.570 & 0.542 & ns & -0.050 & 0.576 & -0.087 & ns & -0.556 & 0.666 & -0.834 & ns & \multirow[t]{5}{*}{ neg. bin. } \\
\hline Margin & 0.483 & 0.359 & 1.345 & ns & 1.052 & 0.437 & 2.407 & $<0.05$ & 1.611 & 0.619 & 2.603 & $<0.01$ & \\
\hline Landscape heterogeneity & -4.950 & 2.747 & -1.802 & ns & -0.002 & 0.009 & -0.190 & ns & 0.010 & 0.009 & 1.027 & ns & \\
\hline Flower coverage in margin & 0.026 & 0.021 & 1.228 & ns & 0.026 & 0.019 & 1.370 & ns & 0.030 & 0.016 & 1.841 & ns & \\
\hline Margin * Landscape heterogeneity & $5 \cdot 352$ & 2.899 & 1.846 & ns & -0.001 & 0.010 & -0.095 & ns & -0.012 & 0.011 & -1.073 & ns & \\
\hline
\end{tabular}


Table 2. continued

\begin{tabular}{|c|c|c|c|c|c|c|c|c|c|c|c|c|c|}
\hline & \multicolumn{4}{|c|}{ Distance to forest (km) } & \multicolumn{4}{|c|}{ Forest (\%) in 500-m buffer } & \multicolumn{4}{|c|}{ Forest (\%) in 1-km buffer } & \multirow[b]{2}{*}{ Model typ } \\
\hline & Estimate & SE & Z & $\mathrm{P}$ & Estimate & SE & Z & $\mathrm{P}$ & Estimate & SE & Z & $\mathrm{P}$ & \\
\hline \multicolumn{14}{|l|}{ Solitary bees } \\
\hline Margin & -0.043 & 0.399 & -0.109 & ns & 0.509 & 0.520 & 0.978 & ns & 0.781 & 0.671 & 1.164 & ns & \multirow{3}{*}{ neg. bin. } \\
\hline Landscape heterogeneity & -5.342 & 2.845 & -1.878 & ns & 0.011 & 0.009 & 1.163 & ns & 0.011 & 0.010 & 1.059 & ns & \\
\hline Flower coverage in margin & -0.030 & 0.027 & -1.123 & ns & -0.024 & 0.028 & -0.857 & ns & -0.023 & 0.028 & -0.843 & ns & \\
\hline \multicolumn{14}{|l|}{ Syrphid flies } \\
\hline (Intercept) & 1.231 & 0.292 & 4.213 & $<0.001$ & -0.589 & 0.412 & -1.429 & & -1.435 & 0.418 & -3.435 & $<0.001$ & \multirow[t]{5}{*}{ neg. bin. } \\
\hline Margin & 0.672 & 0.199 & 3.376 & $<0.001$ & 1.621 & 0.294 & $5 \cdot 512$ & $<0.001$ & 2.243 & 0.271 & 8.278 & $<0.001$ & \\
\hline Landscape heterogeneity & -7.924 & 1.899 & -4.172 & $<0.001$ & 0.024 & 0.006 & 4.305 & $<0.001$ & 0.034 & 0.005 & 6.464 & $<0.001$ & \\
\hline Flower coverage in margin & 0.032 & 0.010 & 3.352 & $<0.001$ & 0.045 & 0.012 & 3.810 & $<0.001$ & 0.044 & 0.013 & 3.514 & $<0.001$ & \\
\hline Margin * Landscape heterogeneity & 4.708 & 2.095 & 2.247 & $<0.05$ & -0.016 & 0.006 & -2.747 & $<0.01$ & -0.024 & 0.004 & -5.443 & $<0.001$ & \\
\hline Margin & 3.776 & 0.570 & 6.625 & $<0.001$ & 3.891 & 0.641 & 6.072 & $<0.001$ & 4.021 & 0.896 & 4.487 & $<0.001$ & \multirow{4}{*}{ poisson } \\
\hline Landscape heterogeneity & -1.516 & 4.188 & -0.362 & ns & 0.001 & 0.016 & 0.069 & ns & 0.005 & 0.017 & 0.313 & ns & \\
\hline Flower coverage in margin & 0.016 & 0.013 & 1.267 & ns & 0.017 & 0.013 & 1.376 & ns & 0.018 & 0.013 & 1.391 & ns & \\
\hline Margin * Landscape heterogeneity & 0.760 & 4.174 & 0.182 & ns & -0.001 & 0.016 & -0.085 & ns & -0.004 & 0.017 & -0.220 & ns & \\
\hline
\end{tabular}


was included as a covariate, and study site as a random factor in the models.

To test whether pollinator occurrence in field margins predicts the number of pollinators visiting the adjacent crop, generalised linear models were applied. Poisson errors were assumed in the models unless the data were overdispersed, in which case negative binomial models were selected. Response variables were species richness, total abundance, and abundances of honeybees, bumblebees, solitary bees, syrphid flies and butterflies in crop fields. Explanatory variables were respective variables (species richness, total abundance, and abundances of honeybees, bumblebees, solitary bees, syrphid flies and butterflies) in field margins. In the crop, species richness and total abundance included minor pollinator groups that were not counted in field margins.

All generalised linear models and generalised linear mixed models were validated by plotting residuals versus fitted values. For total pollinator abundance and honeybee abundance, models were conducted both with and without a field with exceptionally high number of honeybees. For bumblebees, models were conducted with and without a field with exceptional bumblebee abundance. The results of the analyses without these fields were included in the Appendix II.

All statistical analyses were run in R 3.4.1 (R Core Team 2017). Models were fitted using the functions glmmTMB() of the package glmmTMB (Brooks et al. 2017), glm() of the package stats ( $R$ Core Team 2017) and glm.nb() of the package MASS (Venables \& Ripley 2002).

\section{RESULTS}

A total of 948 and 743 pollinator individuals, representing 37 and 21 species or groups, were recorded in the field margins and in the crop, respectively (Tab. A.1). Honeybees composed 51\% of all pollinators visiting the crop, while the shares of all other pollinator groups were below $20 \%$ per group (Tab. A.1). In the field margins, most abundant pollinators were syrphid flies and butterflies (36 and $30 \%$ of all individuals, respectively) (Tab. A.1). All species observed to visit the crop were also found in the margins, except for the minor pollinator groups that were not included in the transect counts in the margins (Tab. A.1).

The mean coverage of insect-pollinated plants in flower in the field margins at the time of the transect counts was $21 \%$ (Tab. 1). The most abundant insect-pollinated plants in the margins were three Apiaceae species recorded as one group (Anthriscus sylvestris, Aegopodium podagraria and Angelica sylvestris), Ranunculus sp., Vicia sp., Lathyrus pratensis and Taraxacum sp.

INTERACTIVE EFFECTS OF HABITAT TYPE AND LANDSCAPE HETEROGENEITY ON POLLINATOR SPECIES RICHNESS AND ABUNDANCE

Pollinators visiting turnip rape were more affected by landscape heterogeneity than pollinators in the adjacent margins (Tab. 2, Fig. $2-$ 3). Pollinator species richness in the crop increased with decreasing distance to forest, and total pollinator abundance increased with increasing cover of forest within the 1-km buffer, whereas, in the field margins, landscape heterogeneity had no effect on species richness or total abundance (Fig. 2). Consequently, differences between the habitat types in pollinator species richness and abundance were largest in landscapes with low landscape heterogeneity (Fig. 2). When one field with exceptionally high number of honeybees was excluded from the analyses, total pollinator abundance responded statistically significantly to the interaction of habitat type with all three landscape heterogeneity measures (Table A.2).

Syrphid flies responded to the interaction of habitat type with all three landscape heterogeneity measures (Tab. 2). When landscape heterogeneity increased, syrphid fly abundance increased faster in the crop than in the field margins (Fig. 3). The interaction between habitat type and landscape heterogeneity did not explain the abundances of honeybees, bumblebees, solitary bees or butterflies (Tab. 2). The coverage of insect-pollinated plants in flower in the field margins was positively related to syrphid fly abundance in the crop fields and margins, but not to other pollinator variables (Tab. 2).

POLLINATOR ABUNDANCE AND SPECIES RICHNESS IN FIELD MARGINS AS PREDICTORS OF THE ABUNDANCE AND SPECIES RICHNESS OF CROP VISITORS

Total pollinator abundance or species richness in the field margins did not explain pollinator 

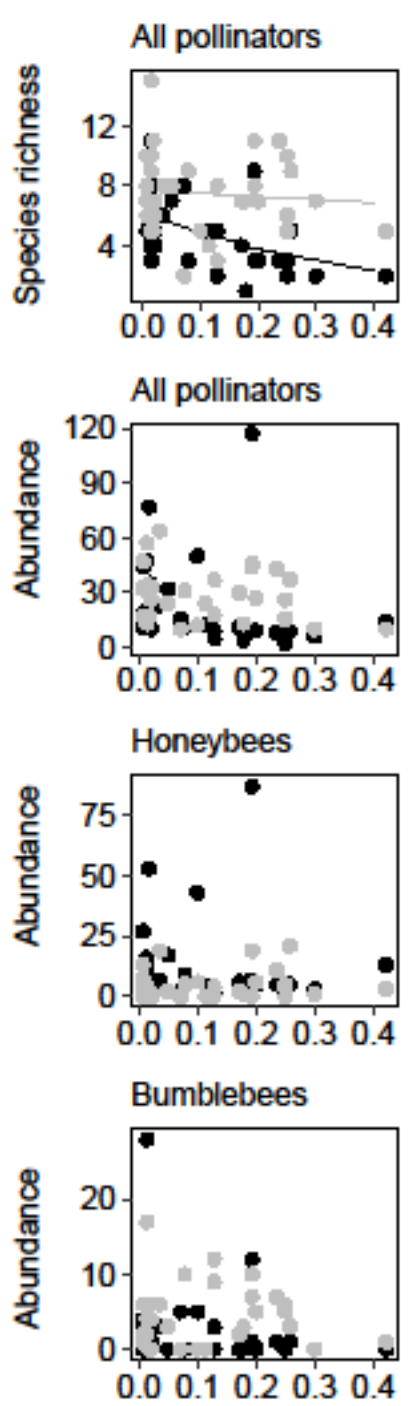

Distance to forest $(\mathrm{km})$
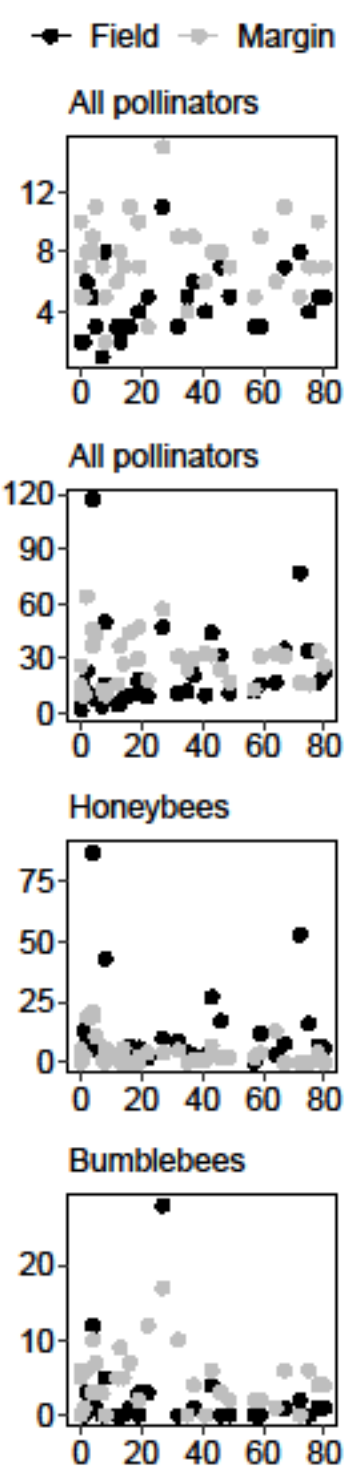

Forest (\%) in $500 \mathrm{~m}$ buffer
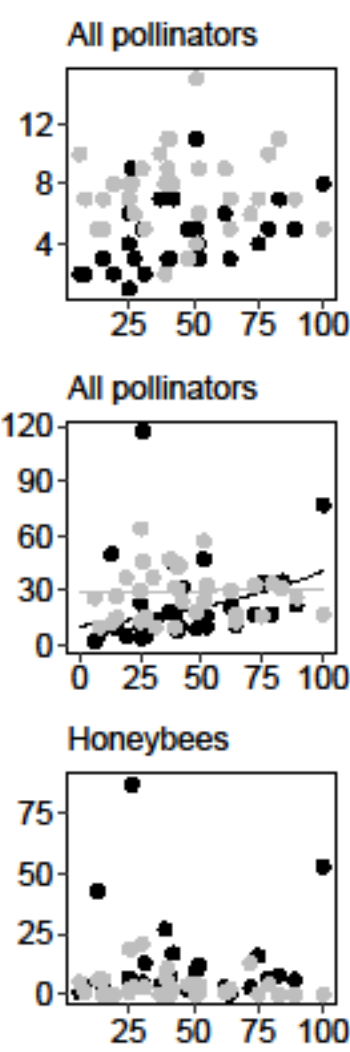

Bumblebees

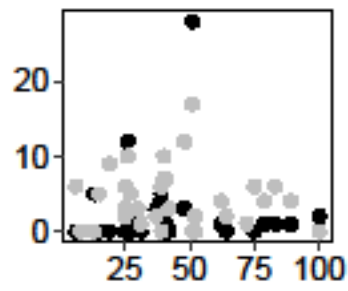

Forest (\%) in $1 \mathrm{~km}$ buffer
FIGURE 2. Species

richness, total pollinator

abundance, and abundances of honeybees and bumblebees visiting turnip rape and occurring in field margins in relation to three measures of landscape heterogeneity (distance to forest, forest cover within the 500-m buffer, and forest cover within the 1-km buffer). Lines in the scatterplots depict predicted values based on generalised linear mixed models with statistically significant interaction between habitat type and landscape heterogeneity (Tab. 2). Due to different pollinator observation methods, species richness and absolute abundances are not directly comparable between fields and margins. abundance or species richness in the turnip rape fields (Tab. 3, Fig. 4). These results remained also if butterflies were excluded from the data (results not shown). High abundances of honeybees and bumblebees in the field margins were related to high numbers of crop visitors in these taxa (Tab. 3, Fig. 4). However, when the fields with exceptionally high honeybee or bumblebee abundance were excluded from the analyses, the statistical significance of the relationship between abundance in field margins and in the crop was lost for honeybees and bumblebees (Tab. A.3).

\section{Discussion}

Pollinator abundance and species richness in field margins were poor indicators of the abundance and species richness of crop-visiting pollinators in adjacent fields. This is probably due to differences in pollinator species composition between the habitats. Although all pollinator groups recorded in field margins were observed to forage on the crop, their relative abundances strongly differed between the habitats. Honeybees preferred the crop to field margins, whereas most wild pollinator species occurring in field margins were rare visitors to, or absent from the crop. This probably results from different dietary and habitat preferences of honeybees and wild pollinators: Honeybees are attracted by mass-flowering plants that enable high foraging efficiency (SteffanDewenter \& Kuhn 2003; Danner et al. 2016). By contrast, wild pollinators may preferentially forage in semi-natural habitats with more 
diversified food resources combined with more nesting opportunities (Rollin et al. 2013; Magrach et al. 2018). Exploitative competition on crop resources, or interference from honeybees may also affect foraging behavior of wild pollinators (Lindström et al. 2016; Mallinger et al. 2017; Nielsen et al. 2017).

Previous studies have reported variable degrees of pollinator sharing between crops and wild plants in adjacent hedgerows and field margins (Stanley \& Stout 2014; Sardiñas \& Kremen 2015; Ganser et al. 2018; Knapp et al. 2019). In our study, crop pollinators represented a subset of pollinators occurring in field margins, and no wild pollinator species showed a preference for turnip rape. However, broad overlaps in pollinator species composition between crop and adjacent edges (Stanley \& Stout 2014), or differences driven by wild crop specialists (Sardiñas \& Kremen 2015) are also possible. The variable results suggest that, while field margins and other semi-natural habitats help a diversity of pollinators to persist in the landscape (Bäckman \& Tiainen 2002; Öckinger \& Smith 2007), their benefits to crop pollination in adjacent fields depend on the characteristics of the crop species and the landscape. In boreal agricultural landscapes with high cover of uncultivated habitats, simply providing seminatural habitats close to crop may inefficiently enhance crop pollination service.

Landscape heterogeneity had a stronger effect on pollinator visitation to turnip rape than on pollinator occurrence in field margins, which is consistent with the findings of Fijen et al. (2019) from a different crop and region. In fielddominated homogenous landscapes, wild pollinators were relatively rare crop visitors even if they occurred in adjacent margins, whereas in heterogeneous landscapes, differences between occurrence in margins and crop visitations were smaller. Possible explanations are that the proximity of uncultivated habitats in heterogeneous landscapes increases the
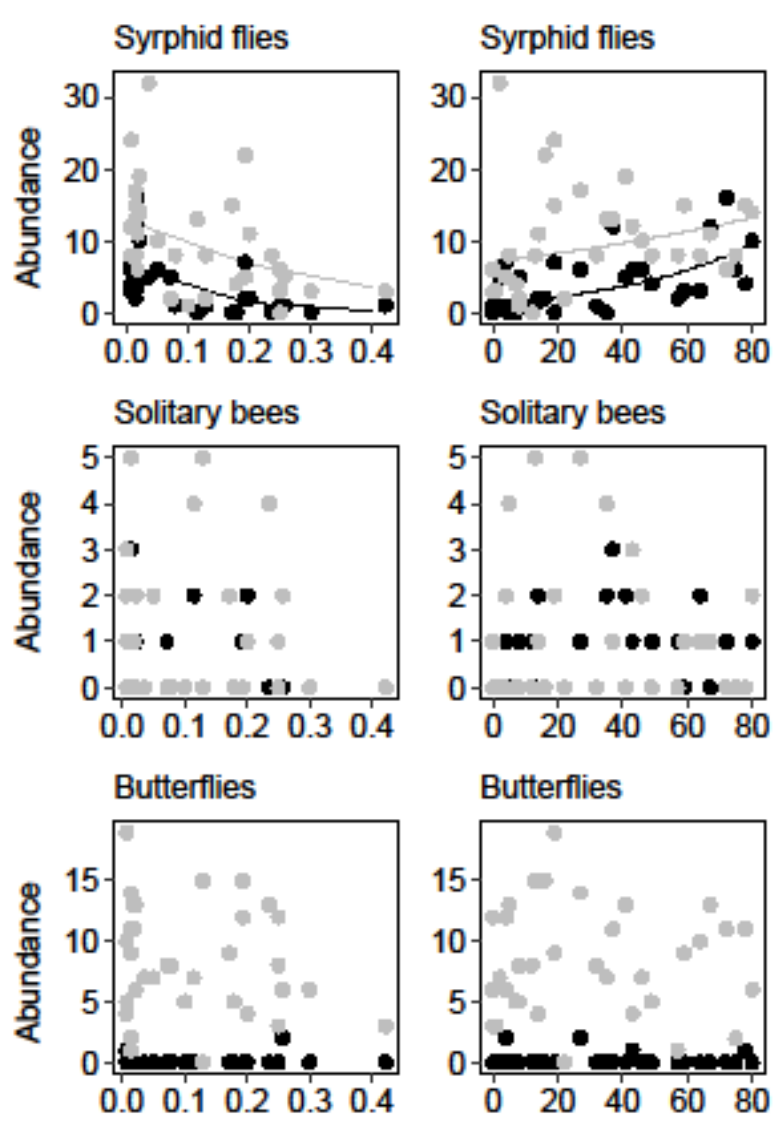

Distance to forest (km) Forest (\%) in $500 \mathrm{~m}$ buffer

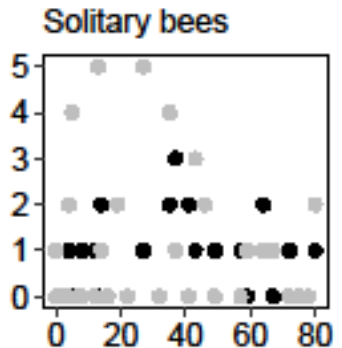

\section{Field $\rightarrow-$ Margin}
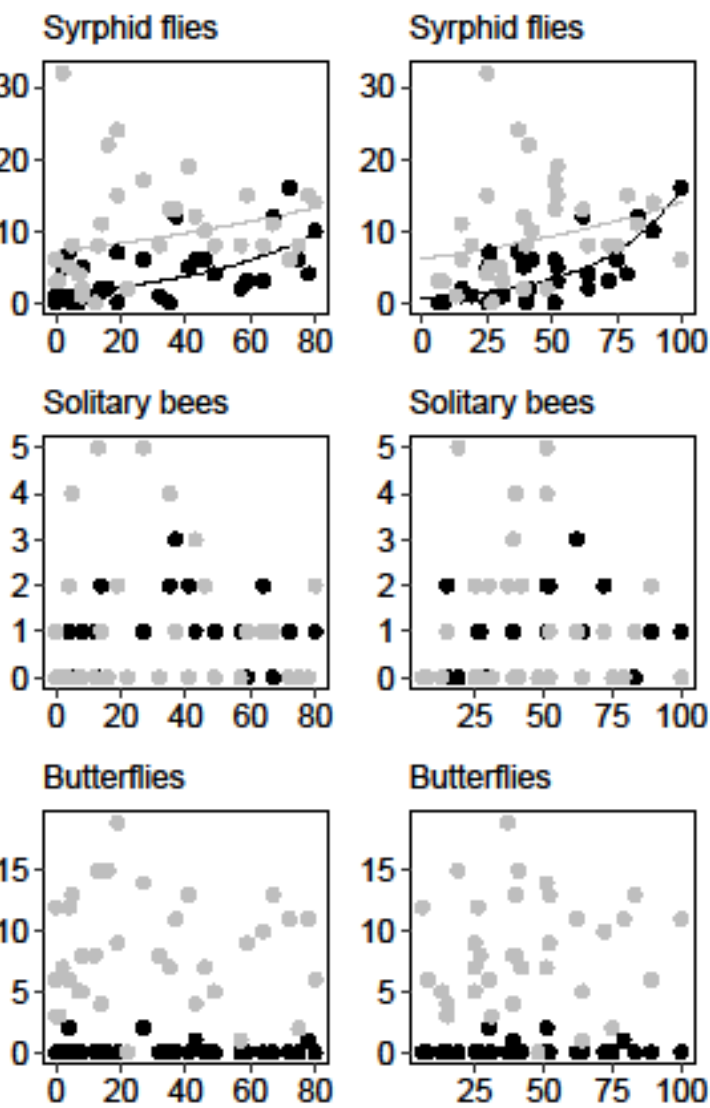

Forest (\%) in $1 \mathrm{~km}$ buffer
FIGURE 3. Abundances of solitary bees, syrphid flies and butterflies visiting turnip rape and occurring in field margins in relation to three measures of landscape heterogeneity (distance to forest, forest cover within the 500-m buffer, and forest cover within the 1-km buffer). Lines in the scatterplots depict predicted values based on generalised linear mixed models with statistically significant interaction between habitat type and landscape heterogeneity (Tab. 2). Due to different pollinator observation methods, species richness and absolute abundances are not directly comparable between fields and margins. 
Table 3. Occurrence frequency, mean abundance and species richness of pollinators in turnip rape fields and field margins, and the results of generalised linear models explaining pollinator abundance and species richness in turnip rape fields with their abundance and species richness in adjacent field margins.

\begin{tabular}{|c|c|c|c|c|c|c|c|c|c|}
\hline & \multicolumn{4}{|c|}{ Summary statistics } & \multicolumn{5}{|c|}{ GLM results } \\
\hline & \multicolumn{2}{|l|}{ Fields } & \multicolumn{7}{|l|}{ Margins } \\
\hline & Freq.-\% & Mean & Freq. $\%$ & Mean & Estimate & SE & Z & $P$ & Model type \\
\hline Pollinator abundance & 100 & 21.9 & 100 & 27.9 & 0.014 & 0.010 & 1.352 & ns & neg. bin. \\
\hline Species richness & 100 & 4.9 & 100 & 7.5 & 0.028 & 0.030 & 0.955 & ns & poisson \\
\hline Honeybees & 94 & 11.2 & 71 & $4 \cdot 3$ & 0.065 & 0.032 & 2.054 & $<0.05$ & neg. bin. \\
\hline Bumblebees & 50 & 2.1 & 79 & $4 \cdot 3$ & 0.155 & 0.067 & 2.292 & $<0.05$ & neg. bin. \\
\hline Solitary bees & 50 & 0.8 & 47 & 1.1 & 0.131 & 0.116 & 1.129 & ns & poisson \\
\hline Syrphid flies & 79 & 3.9 & 97 & 10.0 & 0.044 & 0.025 & 1.751 & ns & neg. bin. \\
\hline Butterflies & 12 & 0.2 & 97 & 8.2 & 0.047 & 0.091 & 0.518 & ns & poisson \\
\hline
\end{tabular}

habitats are attracted by foraging resources provided by the crop, or that pollinator species primarily foraging in uncultivated habitats spill over into crop fields (Tscharnke et al. 2005; Woodcock et al. 2016). Heterogeneous landscapes may also sustain larger populations of wild pollinators that spread from the main habitats to adjacent habitats (Jauker et al. 2009). Furthermore, the larger area of turnip rape and oilseed rape in homogenous landscapes possibly diluted the abundance of those pollinators that were attracted by turnip rape (Holzschuh et al. 2016). In field margins, pollinator occurrence is strongly driven by local availability of flower resources (Lagerlöf et al. 1992; Bäckman \& Tiainen 2002), which is more variable than on a mass-flowering crop field. Most pollinator species were probably able to spread into rewarding field margins regardless of the landscape heterogeneity, due to generally high landscape heterogeneity of our study region, and high connectivity of field margins to other uncultivated habitats.
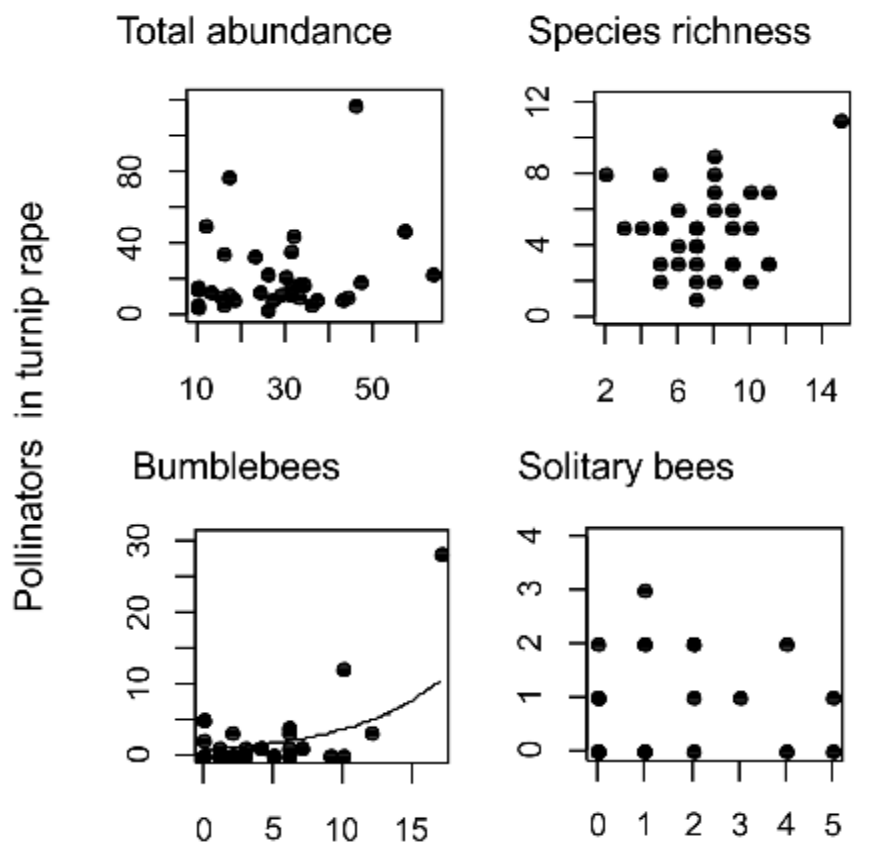

Honeybees

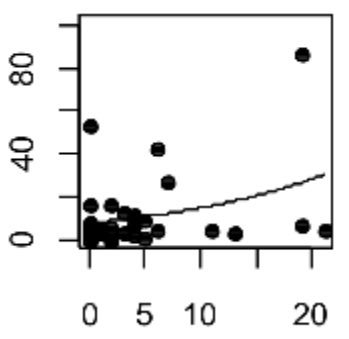

\section{Solitary bees}

Syrphid flies

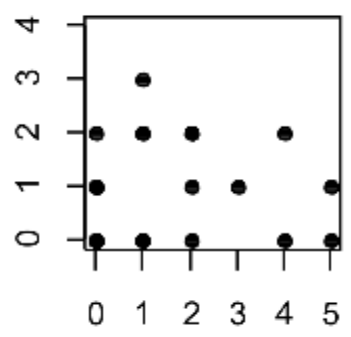

Butterflies

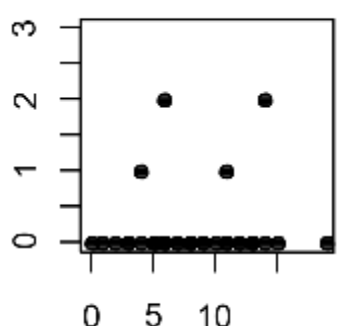

Pollinators in field margins

Figure 4. Pollinator abundance and species richness in turnip rape fields in relation to their abundance and species richness in adjacent field margins. Lines in two scatterplots depict predicted values based on statistically significant generalised linear models (Tab. 3). 
The three measures of landscape heterogeneity produced fairly similar results, when testing the interactive effects of landscape heterogeneity and habitat type on pollinators. However, statistical significance was reached for species richness only when distance to forest was used as a landscape variable, and for total abundance, when forest cover in the 1-km buffer was used as a landscape variable. Since all three measures of landscape heterogeneity were strongly correlated, reliably distinguishing their effects is difficult. However, distance to forest and forest cover probably affected pollinators through partly different mechanisms: high forest cover may be associated with an increased area of semi-natural pollinator habitat in the landscape (Toivonen et al. 2017) and thus affect population sizes of wild pollinators, whereas distance to forest affects how pollinators occurring in the landscape are able to spread into fields.

Pollinator groups differed in their responses to habitat type and landscape heterogeneity. This emphasises the need for considering multiple pollinator groups when predicting the effects of habitat management and landscape structure on pollinator diversity and potential crop pollination services (Jauker et al. 2009; Söderman et al. 2016). Non-bee insects were more dependent on uncultivated habitats than bees: syrphid flies strongly responded to landscape heterogeneity, while butterflies firmly stayed in field margins, thus being insignificant turnip rape pollinators. Besides flower resources to adults, the occurrence of syrphid flies and butterflies is constrained by larval feeding habits (Andersson et al. 2013; Curtis et al. 2015). Woody habitats and open ditches in heterogeneous landscapes may provide larval resources for aphidophagous and saprophagous syrphid flies (Sutherland et al. 2001; Söderman et al. 2016). Although forest may inhibit the dispersal of syrphid flies (Öckinger et al. 2012), it also reduces winds, which is particularly beneficial for small insects (Pasek 1988). Butterflies can also benefit from forest matrix in agricultural landscapes (Toivonen et al. 2017; Bergman et al. 2018). However, the species commonly occurring in field margins mainly feed on grasses and arable herbs as larvae, and may thus benefit less from woody habitats as compared to syrphid flies.
Our study showed a weak link between pollinator occurrence in field margins and pollinator visitation to turnip rape in adjacent fields in boreal agricultural landscapes. This suggests that maintaining and managing field margins does not always enhance pollinator visitation to the crop. Furthermore, surrounding landscape differently affected pollinator occurrence in field margins and crop-visiting pollinators in adjacent fields. The results highlight the need for differentiating between the objectives of pollinator conservation and the delivery of crop pollination services: management strategies designed to enhance one may not efficiently promote the other (Ekroos et al. 2014; Kleijn et al. 2015). Although direct benefits of semi-natural habitats to crop pollination service in adjacent fields are not always certain, these habitats contribute to pollinator conservation, and may enhance other ecosystem services (Holland et al. 2016; Haddaway et al. 2018). More studies quantifying pollination service delivery from semi-natural habitats to crops in different landscape settings and across several years will help develop management approaches to support crop pollination.

\section{ACKNOWLEDGEMENTS}

We are grateful to farmers who participated in the research. We thank Hanne Rajanen for participating in data collection, and Maj and Tor Nessling Foundation and Oiva Kuusisto Foundation for funding the research. We also thank anonymous reviewers for helpful comments on the manuscript.

\section{APPENDICES}

Additional supporting information may be found in the online version of this article:

Appendix I. Species list.

Appendix II. Supplementary analyses.

\section{REFERENCES}

Andersson GKS, Birkhofer K, Rundlöf M, Smith HG (2013) Landscape heterogeneity and farming practice alter the species composition and taxonomic breadth of pollinator communities. Basic and Applied Ecology 14:540-546.

Bäckman JPC, Tiainen J (2002) Habitat quality of field margins in a Finnish farmland area for bumblebees (Hymenoptera: Bombus and Psithyrus). Agriculture, Ecosystems and Environment 89:53-68. 
Bailey S, Requier F, Nusillard B, Roberts SPM, Potts SG, Bouget C (2014) Distance from forest edge affects bee pollinators in oilseed rape fields. Ecology and Evolution 4:370-380.

Baude M, Kunin WE, Boatman ND, Conyers S, Davies N, Gillespie MAK, Morton RD, Smart SM, Memmott J (2016) Historical nectar assessment reveals the fall and rise of floral resources in Britain. Nature 530:85-88.

Bergman KO, Dániel-Ferreira J, Milberg P, Öckinger E, Westerberg L (2018) Butterflies in Swedish grasslands benefit from forest and respond to landscape composition at different spatial scales. Landscape Ecology 33:2189-2204.

Brooks ME, Kristensen K, van Benthem KJ, Magnusson A, Berg CW, Nielsen A, Skaug HJ, Mächler M, Bolker BM (2017) glmmTMB Balances Speed and Flexibility Among Packages for Zero-inflated Generalized Linear Mixed Modeling. The R Journal 9:378-400.

Carvalheiro LG, Seymour CL, Veldtman R, Nicolson SW (2010) Pollination services decline with distance from natural habitat even in biodiversity-rich areas. Journal of Applied Ecology 47:810-820.

Concepción ED, Díaz M, Kleijn D, Báldi A, Batáry P, Clough Y, Gabriel D, Herzog F, Holzschuh A, Knop E, Marshall EJP, Tscharntke T, Verhulst J (2012) Interactive effects of landscape context constrain the effectiveness of local agri-environmental management. Journal of Applied Ecology 49:695-705.

Couvillon MJ, Riddell Pearce FC, Accleton C, Fensome KA, Quah SKL, Taylor EL, Ratnieks FLW (2015) Honey bee foraging distance depends on month and forage type. Apidologie 46:61-70.

Curtis RJ, Brereton TM, Dennis RLH, Carbone C, Isaac, NJB (2015) Butterfly abundance is determined by food availability and is mediated by species traits. Journal of Applied Ecology 52:1676-1684.

Danner N, Molitor AM, Schiele S, Härtel S, SteffanDewenter I (2016) Season and landscape composition affect pollen foraging distances and habitat use of honey bees. Ecological Applications 26:1920-1929.

Ekroos J, Olsson O, Rundlöf M, Wätzold F, Smith HG (2014) Optimizing agri-environment schemes for biodiversity, ecosystem services or both? Biological Conservation 172:65-71.

Esri (2017) ArcGIS Desktop: Release 10.5.1. Environmental Systems Research Institute, Redlands, CA.

Fijen TPM, Scheper JA, Boekelo B, Raemakers I, Kleijn D (2019) Effects of landscape complexity on pollinators are moderated by pollinators' association with massflowering crops. Proceedings of the Royal Society B: Biological Sciences 286:20190387.

Finnish Environment Institute (2014) CORINE Land Cover 2012 database. Publication date: 11.11.2014.
Land cover classification: http://geoportal.ymparisto.fi/meta/julkinen/dokument it/CorineLandCover2012_en.pdf

Ganser D, Mayr B, Albrecht M, Knop E (2018) Wildflower strips enhance pollination in adjacent strawberry crops at the small scale. Ecology and Evolution 8:11775-11784.

Garibaldi LA, Steffan-Dewenter I, Winfree R, Aizen AA, Bommarco R, Cunningham SA, Kremen C, Carvalheiro LG, Harder LD, Afik O, Bartomeus I, Benjamin F, Boreux V, Cariveau D, Chacoff NP, Dudenhöffer JH, Freitas BM, Ghazoul J, Greenleaf S, Hipólito J, Holzschuh A, Howlett B, Isaacs R, Javorek SK, Kennedy CM, Krewenka KM, Krishnan S, Mandelik Y, Mayfield MM, Motzke I, Munyuli T, Nault BA, Otieno M, Petersen J, Pisanty G, Potts SG, Rader R, Ricketts TH, Rundlöf M, Seymour CL, Schüepp C, Szentgyörgyi $\mathrm{H}$, Taki $\mathrm{H}$, Tscharntke $\mathrm{T}$, Vergara $\mathrm{CH}$, Viana $\mathrm{BF}$, Wanger TC, Westphal C, Williams N, Klein AM (2013) Wild pollinators enhance fruit set of crops regardless of honey bee abundance. Science 339:1608-1611.

Garibaldi L, Steffan-Dewenter I, Kremen C, Morales J, Bommarco R, Cunningham S, Carvalheiro LG, Chacoff NP, Dudenhöffer JH, Greenleaf SS, Holzschuh A, Isaacs R, Krewenka K, Mandelik Y, Mayfield MM, Morandin LA, Potts SG, Ricketts TH, Szentgyörgyi H, Viana BF, Westphal C, Winfree R, Klein AM (2011) Stability of pollination services decreases with isolation from natural areas despite honey bee visits. Ecology Letters 14:1062-1072.

Geib J, Strange JP, Galen C (2015) Bumble bee nest abundance, foraging distance, and host-plant reproduction: Implications for management and conservation. Ecological Applications 25:768-778.

Grab H, Blitzer EJ, Danforth B, Loeb G, Poveda K (2017) Temporally dependent pollinator competition and facilitation with mass flowering crops affects yield in co-blooming crops. Scientific Reports 7:45296.

Haaland C, Naisbit RE, Bersier LF (2011) Sown wildflower strips for insect conservation: a review. Insect Conservation and Diversity 4:60-80.

Haddaway NR, Brown C, Eales J, Eggers S, Josefsson J, Kronvang B, Randall NP, Uusi-Kämppä J (2018) The multifunctional roles of vegetated strips around and within agricultural fields. Environmental Evidence $7: 14$

Holland JM, Bianchi FJJA, Entling MH, Moonen AC, Smith BM, Jeanneret P (2016) Structure, function and management of semi-natural habitats for conservation biological control: a review of European studies. Pest Management Science 72:1638-1651.

Holzschuh A, Dainese M, González-Varo JP, MudriStojnić S, Riedinger $\mathrm{V}$, Rundlöf $\mathrm{M}$, Scheper J, Wickens JB, Wickens VJ, Bommarco R, Kleijn D, Potts SG, Roberts SPM, Smith HG, Vilà M, Vujić A, Steffan- 
Dewenter I (2016) Mass-flowering crops dilute pollinator abundance in agricultural landscapes across Europe. Ecology Letters 19:1228-1236.

Jauker F, Diekötter T, Schwarzbach F, Wolters V (2009) Pollinator dispersal in an agricultural matrix: opposing responses of wild bees and hoverflies to landscape structure and distance from main habitat. Landscape Ecology 24:547-555.

Kennedy CM, Lonsdorf E, Neel MC, Williams NM, Ricketts TH, Winfree R, Bommarco R, Brittain C, Burley AL, Cariveau D, Carvalheiro LG, Chacoff NP, Cunningham SA, Danforth BN, Dudenhöffer JH, Elle E, Gaines HR, Garibaldi LA, Gratton C, Holzschuh A, Isaacs R, Javorek SK, Jha S, Klein AM, Krewenka K, Mandelik Y, Mayfield MM, Morandin L, Neame LA, Otieno M, Park M, Potts SG, Rundlöf M, Saez A, Steffan-Dewenter I, Taki H, Viana BF, Westphal C, Wilson JK, Greenleaf SS, Kremen C (2013) A global quantitative synthesis of local and landscape effects on wild bee pollinators in agroecosystems. Ecology Letters 16:584-99.

Kleijn D, Winfree R, Bartomeus I, Carvalheiro LG, Henry M, Isaacs R, Klein AM, Kremen C, M'Gonigle LK, Rader R, Ricketts TH, Williams NM, Adamson NL, Ascher JS, Báldi A, Batáry P, Benjamin F, Biesmeijer JC, Blitzer EJ, Bommarco R, Brand MR, Bretagnolle V, Button L, Cariveau DP, Chifflet R, Colville JF, Danforth BN, Elle E, Garratt MPD, Herzog F, Holzschuh A, Howlett BG, Jauker F, Jha S, Knop E, Krewenka KM, Le Féon V, Mandelik Y, May EA, Park MG, Pisanty G, Reemer M, Riedinger V, Rollin O, Rundlöf M, Sardiñas HS, Scheper J, Sciligo AR, Smith HG, Steffan-Dewenter I, Thorp R, Tscharntke T, Verhulst J, Viana BF, Vaissière BE, Veldtman R, Ward KL, Westphal C, Potts SG (2015) Delivery of crop pollination services is an insufficient argument for wild pollinator conservation. Nature Communications 6:7414.

Knapp JL, Shaw RF, Osborn JL (2019) Pollinator visitation to mass-flowering courgette and coflowering wild flowers: Implications for pollination and bee conservation on farms. Basic and Applied Ecology 34:85-94.

Kovács-Hostyánszki A, Espíndola A, Vanbergen A, Settele J, Kremen C, Dicks LV (2017) Ecological intensification to mitigate impacts of conventional intensive land use on pollinators and pollination. Ecology Letters 20:673-689.

Kremen C, Miles A (2012) Ecosystem services in biologically diversified versus conventional farming systems: benefits, externalities, and trade-offs. Ecology and Society 17:40.

Lagerlöf J, Stark J, Svensson B (1992) Margins of agricultural fields as habitats for pollinating insects. Agriculture, Ecosystems and Environment 40:117-124.
Legendre P, Gallagher ED (2001) Ecologically meaningful transformations for ordination of species data. Oecologia 129:271-280.

Lindström SAM, Herbertsson L, Rundlöf M, Bommarco R, Smith HG (2016) Experimental evidence that honeybees depress wild insect densities in a flowering crop. Proceedings of the Royal Society B: Biological Sciences 283:20161641.

Magrach A, Holzschuh A, Bartomeus I, Riedinger V, Roberts SP, Rundlöf M, Vujić A, Wickens JB, Wickens VJ, Bommarco R, González-Varo JP, Potts SG, Smith HG, Steffan-Dewenter I, Vilà M (2018) Plant-pollinator networks in semi-natural grasslands are resistant to the loss of pollinators during blooming of mass-flowering crops. Ecography 41:62-74.

Mallinger RE, Gaines-Day HR, Gratton C (2017) Do managed bees have negative effects on wild bees?: A systematic review of the literature. PLOS ONE 12:e0189268.

M'Gonigle LK, Ponisio L, Cutler K, Kremen C (2015) Habitat restoration promotes pollinator persistence and colonization in intensively-managed agriculture. Ecological Applications 25:1557-1565.

Nielsen A, Reitan T, Rinvoll AW, Brysting AK (2017) Effects of competition and climate on a crop pollinator community. Agriculture, Ecosystems and Environment 246:253-260.

Öckinger E, Lindborg R, Sjödin NE, Bommarco R (2012) Landscape matrix modifies richness of plants and insects in grassland fragments. Ecography 35:259-267.

Öckinger E, Smith HG (2007) Semi-natural grasslands as population sources for pollinating insects in agricultural landscapes. Journal of Applied Ecology 44:50-59.

Pasek E (1988) Influence of wind and windbreaks on local dispersal of insects. Agriculture, Ecosystems and Environment 22-23:539-554.

Phillips BB, Williams A, Osborne JL, Shaw RF (2018) Shared traits make flies and bees effective pollinators of oilseed rape (Brassica napus L.). Basic and Applied Ecology 32:66-76.

Pollard E, Yates T (1993) Monitoring Butterflies for Ecology and Conservation. Chapman and Hall, London.

Potts SG, Imperatriz-Fonseca V, Ngo HT, Aizen MA, Biesmeijer JC, Breeze TD, Dicks LV,

Garibaldi LA, Hill R, Settele J, Vanbergen AJ (2016) Safeguarding pollinators and their values to human well-being. Nature 540:220-229.

R Core Team (2017) R: A language and environment for statistical computing. R Foundation for Statistical Computing, Vienna. https://www.r-project.org/

Redhead JW, Dreier S, Bourke AFG, Heard MS, Jordan WC, Sumner S, Wang J, Carvell C (2016) Effects of 
habitat composition and landscape structure on worker foraging distances of five bumble bee species. Ecological Applications 26:726-739.

Ricketts TH, Regetz J, Steffan-Dewenter I, Cunningham SA, Kremen C, Bogdanski A, Gemmill-Herren B, Greenleaf SS, Klein AM, Mayfield MM, Morandin LA, Ochieng A, Viana BF (2008) Landscape effects on crop pollination services: Are there general patterns? Ecology Letters 11:499-515.

Rollin O, Bretagnolle V, Decourtye A, Aptel J, Michel N, Vaissière BE, Henry M (2013) Differences of floral resource use between honey bees and wild bees in an intensive farming system. Agriculture, Ecosystems and Environment 179:78-86.

Sardiñas HS, Kremen C (2015) Pollination services from field-scale agricultural diversification may be contextdependent. Agriculture, Ecosystems and Environment 207:17-25.

Scheper J, Reemer M, van Kats R, Ozinga WA, van der Linden GTJ, Schaminée JHJ, Siepel H, Kleijn D (2014) Museum specimens reveal loss of pollen host plants as key factor driving wild bee decline in the Netherlands. Proceedings of the National Academy of Sciences 111:17552-17557.

Scheper J, Holzschuh A, Kuussaari M, Potts SG, Rundlöf M, Smith HG, Kleijn D (2013) Environmental factors driving the effectiveness of European agrienvironmental measures in mitigating pollinator loss a meta-analysis. Ecology Letters 16:912-920.

Söderman AME, Ekroos J, Hedlund K, Olsson O, Smith HG (2016) Contrasting effects of field boundary management on three pollinator groups. Insect Conservation and Diversity 9:427-437.

Stanley DA, Stout JC (2014) Pollinator sharing between mass-flowering oilseed rape and co-flowering wild plants: implications for wild plant pollination. Plant Ecology 215:315-325.

Steffan-Dewenter I, Kuhn A (2003) Honeybee foraging in differentially structured landscapes. Proceedings of the Royal Society B: Biological Sciences 270:569-575.
Sutherland JP, Sullivan MS, Poppy GM (2001) Distribution and abundance of aphidophagous hoverflies (Diptera: Syrphidae) in wildflower patches and field margin habitats. Agricultural and Forest Entomology 3:57-64.

Toivonen M, Herzon I, Kuussaari M (2015) Differing effects of fallow type and landscape structure on the occurrence of plants, pollinators and birds on environmental fallows in Finland. Biological Conservation 181:36-43.

Toivonen M, Herzon I, Rajanen H, Toikkanen J, Kuussaari M (2019) Late flowering time enhances insect pollination of turnip rape. Journal of Applied Ecology 56:1164-1175.

Toivonen M, Peltonen A, Herzon I, Heliölä J, Leikola N, Kuussaari M (2017) High cover of forest increases the abundance of most grassland butterflies in boreal farmland. Insect Conservation and Diversity 10:321330.

Tscharnke T, Rand TA, Bianchi FJJA (2005) The landscape context of trophic interactions: insect spillover across the crop-noncrop interface. Annales Zoologici Fennici 42:421-432.

Venables WN, Ripley BD (2002) Modern Applied Statistics with S. Fourth Edition. Springer, New York.

Westphal C, Bommarco R, Carré G, Lamborn E, Morison N, Petanidou T, Potts SG, Roberts SPM, Szentgyörgyi $H$, Tscheulin $T$, Vaissière BE, Woyciechowski $M$, Biesmeijer JC, Kunin WE, Settele J, Steffan-Dewenter I (2008) Measuring bee biodiversity in different European habitats and biogeographical regions. Ecological Monographs 78:653-671.

Woodcock BA, Bullock JM, McCracken M, Chapman RE, Ball SL, Edwards ME, Nowakowski M, Pywell RF (2016) Spill-over of pest control and pollination services into arable crops. Agriculture, Ecosystems and Environment 231:15-23. 